\title{
A mini review on orthodontic-endodontic management of root resorption induced by ectopic canine
}

\begin{abstract}
The purpose of this literature review was to screen the valuable indexed published articles regarding the Orthodontic and Endodontic Management of root resorption induced by ectopic canine. The searching was performed on the Pubmed using MeSH words such as" root resorption, ectopic canine, endsodontic management, orthodontic management". A total of 14 articles were selected, In conclusion, proper clinical investigation and orthodontic and endodontic management can lead to good long term prognosis.
\end{abstract}

Volume 5 Issue I - 2016

\author{
Deema Al Shammery,' Musaed Al Tammami² \\ 'Department of Orthodontist, Riyadh Colleges of Dentistry and \\ Pharmacy, Saudi Arabia \\ ${ }^{2}$ Department of Endodontist, Security Forces Hospital, Saudi \\ Arabia
}

\begin{abstract}
Correspondence: Deema Al-Shammery, Department of Orthodontist, Riyadh Colleges of Dentistry and Pharmacy, Saudi
\end{abstract} Arabia,Email deema@riyadh.edu.sa

Received: September 10, 2016 | Published: September I5, 2016

\section{Introduction}

The incidence of impacted or ectopically erupting maxillary permanent canines has been reported to be 0.9 to 2.0 percent. ${ }^{1,2}$ Many complications associated with Ectopically erupting and untreated impacted canines has been reported in the literature, such as displacement of the adjacent incisors, formation of follicular cysts, canine ankylosis, canine internal resorption, external resorption of the canine and roots of adjacent teeth, shortening of the dental arch, and/or combinations of these conditions. Root resorption of the adjacent permanent teeth is one of the most important and frequent complications. ${ }^{3}$ Incidence of Lateral incisor root resorption adjacent to ectopically erupted canines has been reported. Approximately 0.7 percent, It was found that even with continued root development, an abnormally erupting canine can harm the adjacent lateral incisor., Several possible causative factors of root resorption associated with ectopic maxillary canines have been considered in the literature. Such as pressure and inclination of the erupting canine, follicular activity, orthodontic forces, genetics, trauma, developmental insufficiencies of immature roots, and their susceptibility to resorptive enzymes. But the exact etiology is known. ${ }^{2-8}$

\section{Clinical investigation}

It was found that root resorption can be difficult to diagnose because its progress is asymptomatic and rapid. In addition to that, it can penetrate the pulpal canal and/or radically reducing crown root ratio that will lead to loss of the affected teeth. ${ }^{4}$ Assessing the position of the impacted canine is the key to determining the feasibility of and proper management, as well as the best direction for application of orthodontic forces and orthodontic treatment. ${ }^{9}$ Cone-beam computed tomography (CBCT) considered as one of the best method that can identify and locate the position of impacted canines accurately. It facilitates the assessment of any damage to the roots of adjacent teeth and the amount of bone surrounding each tooth. ${ }^{10}$ It has found that CT detects $50 \%$ more cases of resorption than intraoral and panoramic radiography. ${ }^{2}$ It has been reported that evidence obtained from the CT investigation resulted in changes in the treatment plans $43 \%$ of the tim. ${ }^{11}$

\section{Orthodontic management}

When root resorption occurs, Multiple factors determine the choice of treatment. Orthodontic treatment planning should include comprehensive examination to determine the presence of resorption of incisor roots and if so, the site and severity of the resorption. It has been reported that once the impacted canine has been treated orthodontically, there is no risk for further resorption. ${ }^{12}$

\section{Endodontic management}

Endodontic treatment of resorptive lesion induced by ectopically erupted or impacted canine was debatable. Some authors stated that there is no indication for endodontic treatment to arrest further root resorption, and the long-term prognosis for maxillary incisors with root resorption associated with ectopically positioned canines is good, once the impacted canine has been treated orthodontically. It has been reported that even in cases with severe resorption, the incisor roots show good long-term healing. ${ }^{8}$ In the other hand, other authors reported a case in which progression of the lesion had necessitated endodontic treatment. ${ }^{13}$ They found that endodontically treated incisors resorbed with less frequency and severity than vital control teeth. ${ }^{14}$

\section{Conclusion}

Based on current literature, Regardless the severity of root resorption induced by ectopic canine eruption, Proper clinical investigation and orthodontic and endodontic management can lead to good long term prognosis. 


\section{Funding}

None.

\section{Acknowledgments}

None.

\section{Conflicts of interest}

Authors declare that there is no conflict of interest.

\section{References}

1. Thilander B, Jakobsson SO. Local factors in impaction of maxillary canines. Acta Odontol Scand. 1968;26(2):145-168.

2. Ericson S, Kurol J. Radiographic examination of ectopically erupting maxillary canines. Am J Orthod Dentofacial Orthop. 1987;91(6):483-492.

3. Shafer WG, Hine MK, Levy BM. A textbook of oral pathology. 3rd ed. WB Sauders: Philadelphia, Pennsylvania, USA; 1974. 1-853 p.

4. Bjerklin K, Ericson S. How a computerized tomography (CT) examination changed the treatment plans of 80 children with retained and ectopically positioned maxillary canines. Angle Orthod. 2006;76(1):43-51.

5. Ericson S, Bjerklin K, Falahat B. Does the canine dental follicle cause resorption of permanent incisor roots? A computed tomographic study of erupting maxillary canines. Angle Orthodontist. 2002;72(2):95-104.

6. Becker A. The orthodontic treatment of impacted teeth. 2nd ed. Informa London, UK; 2007. 23-93 p.
7. Falahat B, Ericson S, Mak D'Amico R, et al. Incisor root resorption due to ectopic maxillary canines: a long-term radiographic follow-up. Angle Orthod. 2008;78(5):778-785.

8. Bishara SE. Impacted maxillary canines: a review. Am J Orthod Dentofacial Orthop. 1992;101(2):159-171.

9. Liu DG, Zhang WL, Zang ZY et al. Localization of impacted maxillary canines and observation of adjacent incisor resorption with cone-beam computed tomography. Oral Surg Oral Med Oral Pathol Oral Radiol Endod. 2008;105(1):91-98.

10. Ericson S, Kurol J. Incisor root resorptions due to ectopic maxillary canines imaged by computerised tomography: a comparative study in extracted teeth. Angle Orthod. 2000;70(4):276-283.

11. Kurol J, Ericson S, Andreason JO. The impacted maxillary canine. In: Andreasen JO, Petersson JK, Laskin DM, (Ed). Textbook and Color Atlas of Tooth Impactions. Munksgaard: Denmark, Europe; 1997. 129-130 p.

12. Becker A, Chaushu S. Long-term follow-up of severely resorbed maxillary incisors after resolution of an etiologically associated impacted canine. Am J Orthod Dentofacial Orthop. 2005;127(6):650-654.

13. Bjerklin K, Kurol J, Valentin J. Ectopic eruption of maxillary first permanent molars and association with other tooth and developmental disturbances. Eur J Orthod. 1992;14(5):369-375.

14. Spurrier SW, Hall SH, Joondeph DR, et al. A comparison of apical root resorption during orthodontic treatment in endodontically treated and vital teeth. AM J Othod Dentofac Orthop. 1990;97(2):130-134. 